\title{
The Determinant of Coping Mechanisms among Breast Cancer Patients in Sidoarjo Regency, Indonesia
}

\author{
Masruroh $^{1,2}$, Ah Yusuf ${ }^{3}$, Agung Dwi Laksono ${ }^{4}$ \\ ${ }^{1}$ Doctoral Program, Faculty of Public Health, Universitas Airlangga, Surabaya Indonesia, ${ }^{2}$ Faculty of Health \\ Science Universitas Pesantren Tinggi Darul Ulum, Jombang, Indonesia, ${ }^{3}$ Faculty of Nursing, Universitas \\ Airlangga, Surabaya Indonesia, ${ }^{4}$ National Institute of Health Research and Development, Indonesia Ministry of \\ Health, Jakarta, Indonesia
}

\begin{abstract}
Breast cancer patients need coping mechanisms to adapt to changes due to breast cancer. The constructive coping mechanism is very influential on the attitude, response, decision making towards breast cancer management, and quality of life. The study aimed to determine the determinants of coping mechanisms of breast cancer patients in Sidoarjo Regency, Indonesia. The sample size was 98 breast cancer patients. The variables analyzed included coping mechanism, age, educational, marital, work, time diagnosed, genetic, stage of cancer, therapy, social support, and spiritual need. The results found that breast cancer patients with higher education had a 51.200 times chance compared to breast cancer patients with no education to have adaptive coping mechanisms. Therapy for breast cancer patients has a positive effect on adaptive coping mechanisms. Social support has a positive influence on breast cancer patients to have an adaptive coping mechanism. The higher the social support provided, the more adaptive coping mechanism is for breast cancer patients. Tree variables have proven to be significant as determinants of coping mechanisms among breast cancer patients in the Sidoarjo Regency, namely education, therapy, and social support.
\end{abstract}

Keywords: Breast cancer, coping mechanisms, spiritual needs, social support, education.

\section{Introduction}

Breast cancer is a malignant tumor originating from breast cells. Breast cancer can originate from cells that produce mammary glands (lobular), glandular ducts from lobular to nipple (ducts), and supporting breast tissue that surrounds the lobular, ducts, blood vessels, and lymph vessels, but does not include breast skin ${ }^{1}$.

Breast cancer is the highest type of cancer in women in the world. The incidence of breast cancer increased from 26 per 100,000 to 38 per 100,000 women. This prevalence is above cervical cancer with a record of 16 per 100,000 women $^{2}$. In Indonesia, the prevalence

\footnotetext{
Corresponding Author: Agung Dwi Laksono

National Institute of Health Research and Development, Indonesia Ministry of Health,Jakarta, Indonesia e-mail: agung.dwi.laksono-2016@fkm.unair.ac.id
}

of cancer is 1.4 per 1,000 population and is the 7 th leading cause of death $(5.7 \%)$ of all causes of death. The estimated incidence of breast cancer in Indonesia is 40 per 100,000 and cervical cancer 17 per 100,000 women ${ }^{2}$. While breast cancer incidence in East Java was ranked first in Indonesia ${ }^{3}$.

Cancer diagnosis and management are stressors that affect all aspects of a patient's life. Changes occur in the physical, psychological, social, and spiritual of the patient ${ }^{4}$. Diagnosis and treatment of breast cancer is the highest stress, and causes of psychosocial disorders. Breast cancer patients face uncertainty and fear of cancer diagnosis, management, and recovery. Individuals diagnosed with breast cancer generally face a variety of invasive medical procedures with many potential negative side effects (eg pain, nausea, vomiting, lymphedema, hair loss). High-stress levels can cause long-term negative effects on psychosocial breast cancer patients $^{5}$. Other psychological reactions that commonly occur due to a diagnosis of breast cancer are distress, 
shock, impaired self-concept, anxiety, depression, loss of control, helplessness, difficulty concentrating, despair, loss of zest for life. The psychological impact of breast cancer $80 \%$ causes the patient to distress, $16 \%$ feel close to death, $3 \%$ angry, and $1 \%$ can accept the condition ${ }^{6}$. The impact of breast cancer also results in physiological incapability, psychological disequilibrium, social relationship misbehavior, spiritual values disparity, and life of courage ${ }^{7}$. These changes will have an impact on the quality of life of breast cancer patients.

Breast cancer patients need coping mechanisms to adapt to changes due to breast cancer. The constructive coping mechanism is very influential on the attitude, response, decision making towards breast cancer management, and quality of life ${ }^{8}$. Identifying the factors that influence coping mechanisms is important. Some factors that influence coping mechanisms are age, sex, perception of disease, personality, and social and cultural conditions, spiritual needs, social support, and demographic factor ${ }^{8,9}$. Previous research found that the constructive coping mechanism is very influential on the quality of life of breast cancer patients. Identifying factors that influence the coping mechanism for breast cancer patients can provide specific interventions to overcome psychosocial problems that occur in breast cancer patients ${ }^{10}$. Based on the background description, the study aimed to determine the determinants of coping mechanisms of breast cancer patients at SidoarjoRegency, Indonesia.

\section{Materials and Method}

This study was an observational analytic study with a cross-sectional design. The study population was all patients who had been diagnosed with breast cancer by a doctor in Sidoarjo Regency. The number of samples was 98 patients with a diagnosis of breast cancer. The dependent variable is the coping mechanism, which consists of adaptive and maladaptive coping mechanisms. The independent variables are age group, educational level, marital status, work status, time diagnosed, the genetic, stadium of cancer, therapy, social support, and spiritual need. The final stage was analyzed multivariate with binary logistic regression.

Coping mechanisms are cognitive and behavioral changes that are constant to overcome certain internal or external demands that are tiring or exceed individual sources ${ }^{11}$. The coping mechanism can be described as handling related to problems and situations ${ }^{12}$. An adaptive coping mechanism is a coping mechanism that supports the function of integration, growth, learning and achieving goals. Adaptive coping mechanisms include talking to others about the problem being faced to find alternative solutions, trying to find more information about the problem being faced, praying, doing physical exercises to reduce the tension of the problem, making various alternative actions to reduce the situation, and feel confident that all will return to stable, take lessons from past events or experiences. Maladaptive coping mechanisms are coping mechanisms that inhibit the function of integration, solve growth, reduce autonomy, and tend to control the environment. Maladaptive behavior includes aggressive behavior and withdrawal. physically and psychologically individuals consciously leave the environment that is the source of stressors such as individuals fleeing from sources of stress ${ }^{13}$.

Social support is any form of effort provided by others, close relatives, breast cancer patient peer groups in adapting to their illness, which includes emotional, judgment, information, instrumental. Emotional support is any effort given by family and closest people to breast cancer patients through feelings of care, attention, affection, and love, so that breast cancer patients feel comfortable. Appraisal support is any form of support carried out by family and loved ones through positive expressions, positive support for breast cancer patients. Information support is support from health workers and families to breast cancer patients through the provision of information about the disease so that patients understand the disease and its condition. Instrumental support is the support given by the family in the form of material to breast cancer patients.

Spiritual needs in sufferers of chronic diseases include relationships, peace, meaning/purpose, and transcendence, which can be related to the psychosocial, emotional, existential, and religious needs that underlie them. Spiritual needs are the need for trust, the need to express personal trust, the need to maintain the spiritual practice, and trust in God. Questionnaire to measure the spiritual needs of patients, using the Spiritual Needs Questionnaire $^{14}$

\section{Results and Discussion}

Table 1 displays descriptive statistics of breast cancer patients in SidoarjoRegency, Indonesia. Based on the age group, the two types of coping mechanisms are dominated by patients in the 46-55 age group. Based 
on education level, breast cancer patients who are maladaptive in the coping mechanism are dominated by patients who have primary education, while breast cancer patients who are adaptive in the coping mechanism are dominated by patients who have higher education, secondary education. Based on marital status, the two types of coping mechanisms are dominated by married patients. Based on work status, both types of coping mechanisms are dominated by patients having work.

Based on time diagnosed, breast cancer patients who are maladaptive in the coping mechanism are dominated by patients diagnosed for less than 1 year, while adaptive breast cancer patients in the coping mechanism are dominated by patients who are diagnosed for more than 1 year. Based on genetic variables, both types of coping mechanisms are dominated by patients who have breast cancer lineage. Based on therapy, breast cancer patients who are maladaptive in the coping mechanism are dominated by patients who have not done therapy, while breast cancer patients who are adaptive in the coping mechanism are dominated by patients who have finished doing therapy.

Table 1. Descriptive statistics of the breast cancer patient in Sidoarjo Regency, Indonesia, 2019 (n=98)

\begin{tabular}{|c|c|c|c|c|c|}
\hline \multirow{3}{*}{ Variable } & \multicolumn{4}{|c|}{ Coping Mechanism } & \multirow{3}{*}{$\mathbf{P}$} \\
\hline & \multicolumn{2}{|c|}{ Maladaptive } & \multicolumn{2}{|c|}{ Adaptive } & \\
\hline & $\mathbf{n}$ & $\%$ & n & $\%$ & \\
\hline Age groups & & & & & 0.468 \\
\hline$<26$ & 2 & $4.3 \%$ & 1 & $1.9 \%$ & \\
\hline $26-35$ & 5 & $10.9 \%$ & 1 & $1.9 \%$ & \\
\hline $36-45$ & 13 & $28.3 \%$ & 17 & $32.7 \%$ & \\
\hline $46-55$ & 16 & $34.8 \%$ & 21 & $40.4 \%$ & \\
\hline $56-65$ & 7 & $15.2 \%$ & 10 & $19.2 \%$ & \\
\hline$>65$ & 3 & $6.5 \%$ & 2 & $3.8 \%$ & \\
\hline Education & & & & & $* 0.011$ \\
\hline No education & 6 & $13.0 \%$ & 1 & $1.9 \%$ & \\
\hline Primary & 21 & $45.7 \%$ & 14 & $26.9 \%$ & \\
\hline Secondary & 14 & $30.4 \%$ & 23 & $44.2 \%$ & \\
\hline Higher & 5 & $10.9 \%$ & 14 & $26.9 \%$ & \\
\hline Marital & & & & & 0.900 \\
\hline Single & 2 & $4.3 \%$ & 2 & $3.8 \%$ & \\
\hline Married & 44 & $95.7 \%$ & 50 & $96.2 \%$ & \\
\hline Work status & & & & & 0.528 \\
\hline Not work & 30 & $65.2 \%$ & 37 & $71.2 \%$ & \\
\hline Work & 16 & $34.8 \%$ & 15 & $28.8 \%$ & \\
\hline Time diagnosed & & & & & $* * 0.001$ \\
\hline$\leq 1$ year & 27 & $58.7 \%$ & 13 & $25.0 \%$ & \\
\hline$>1$ year & 19 & $41.3 \%$ & 39 & $75.0 \%$ & \\
\hline Genetik & & & & & 0.907 \\
\hline No & 20 & $43.5 \%$ & 22 & $42.3 \%$ & \\
\hline Yes & 26 & $56.5 \%$ & 30 & $57.7 \%$ & \\
\hline Stadium & & & & & $* 0.019$ \\
\hline$\leq 2$ & 22 & $47.8 \%$ & 13 & $25.0 \%$ & \\
\hline
\end{tabular}




\begin{tabular}{|c|c|c|c|c|c|}
\hline \multirow{3}{*}{ Variable } & \multicolumn{4}{|c|}{ Coping Mechanism } & \multirow{3}{*}{$\mathbf{P}$} \\
\hline & \multicolumn{2}{|c|}{ Maladaptive } & \multicolumn{2}{|c|}{ Adaptive } & \\
\hline & $\mathrm{n}$ & $\%$ & $\mathrm{n}$ & $\%$ & \\
\hline$\geq 3$ & 24 & $52.2 \%$ & 39 & $75.0 \%$ & \\
\hline Therapy & & & & & $* * *<0.001$ \\
\hline Not yet & 22 & $47.8 \%$ & 6 & $11.5 \%$ & \\
\hline On progress & 12 & $26.1 \%$ & 11 & $21.2 \%$ & \\
\hline Finished & 12 & $26.1 \%$ & 35 & $67.3 \%$ & \\
\hline Social support & & & & & $* * *<0.001$ \\
\hline Low & 23 & $50.0 \%$ & 4 & $7.7 \%$ & \\
\hline Medium & 20 & $43.5 \%$ & 26 & $50.0 \%$ & \\
\hline High & 3 & $6.5 \%$ & 22 & $42.3 \%$ & \\
\hline Spiritual needs & & & & & $* * 0.007$ \\
\hline Low & 10 & $21.7 \%$ & 2 & $3.8 \%$ & \\
\hline Medium & 20 & $43.5 \%$ & 19 & $36.5 \%$ & \\
\hline High & 16 & $34.8 \%$ & 31 & $59.6 \%$ & \\
\hline
\end{tabular}

Note: ${ }^{*} \mathrm{p}<0.05 ;{ }^{* *} \mathrm{p}<0.01 ; * * * \mathrm{p}<0.001$.

Based on social support, breast cancer patients who are maladaptive in the coping mechanism are dominated by patients who have low social support, while breast cancer patients who are adaptive in the coping mechanism are dominated by patients who have social support medium. Based on spiritual needs, breast cancer patients who are maladaptive in the coping mechanism are dominated by patients who have spiritual needs medium category, while breast cancer patients who are adaptive in the coping mechanism are dominated by patients who have spiritual needs high category.
Table 2 shows the results of the binary logistic regression of coping mechanisms among breast cancer patients. Based on the level of education, it appears that breast cancer patients with higher education have 51.200 times chance compared to breast cancer patients with no education to have an adaptive coping mechanism (OR 51.200; 95\% CI 1.575-1664.335). The results of this analysis inform us that the level of education has a positive influence on coping mechanisms that are adaptive for breast cancer patients.

Tabel 2. The result of binary logistic regression of coping mechanism among breast cancer patient in Sidoarjo Regency, Indonesia, 2019 (n=98)

\begin{tabular}{|c|c|c|c|c|}
\hline \multirow{2}{*}{ Predictors } & \multirow{2}{*}{ Sig. } & \multicolumn{3}{|c|}{ Coping Mechanism } \\
\hline & & OR & LB & UB \\
\hline Education: No education & - & - & - & - \\
\hline Education: Primary & 0.433 & 2.855 & 0.208 & 39.259 \\
\hline Education: Secondary & 0.484 & 2.643 & 0.174 & 40.115 \\
\hline Education: Higher & $* 0.027$ & 51.200 & 1.575 & 1664.335 \\
\hline Time diagnosed: $\leq 1$ year & - & - & - & - \\
\hline Time diagnosed: $>1$ year & 0.060 & 6.737 & 0.920 & 49.317 \\
\hline Stadium: $\leq 2$ & - & - & - & - \\
\hline Stadium: $\geq 3$ & 0.228 & 3.067 & 0.496 & 18.952 \\
\hline Therapy: Not yet & - & - & - & - \\
\hline
\end{tabular}




\begin{tabular}{|l|c|c|c|c|}
\hline \multirow{2}{*}{ Predictors } & \multirow{2}{*}{ Sig. } & \multicolumn{3}{|c|}{ Coping Mechanism } \\
\cline { 3 - 5 } & & OR & LB & 1.429 \\
\hline Therapy: On progress & $* 0.022$ & 12.467 & 2.213 & 108.736 \\
\hline Therapy: Finished & $* * 0.006$ & 14.958 & - & 101.105 \\
\hline Social support: Low & - & - & 1.469 & - \\
\hline Social support: Medium & $* 0.016$ & 7.561 & 14.154 & 38.916 \\
\hline Social support: High & $* * *<0.001$ & 225.419 & - & - \\
\hline Spiritual needs: Low & - & - & 0.109 & 11.706 \\
\hline Spiritual needs: Medium & 0.919 & 1.128 & 0.289 & 33.636 \\
\hline Spiritual needs: High & 0.349 & 3.119 & & -974 \\
\hline
\end{tabular}

Note: ${ }^{*} \mathrm{p}<0.05 ;{ }^{* *} \mathrm{p}<0.01 ; * * * \mathrm{p}<0.001$.

The better level of education makes breast cancer patients more receptive to the conditions that are undergoing higher education are more likely to be able to adapt to breast cancer, this is possible because access to sources of information is easier to do. These results are consistent with research conducted in Iran showing that higher education is more likely to be able to adapt to breast cancer, this is possible because access to information sources is easier to do. This finding is in line with several previous studies in Norway proving that educational level was the most important contributor to social support, Educational was positively related to instrumental-oriented coping ${ }^{15}$.Previous studies have suggested that education are often found to have a positive impact on various programs in the health sector $^{16-19}$.

The breast cancer patient who is undergoing therapy has a 12.467 times chance compared to breast cancer patients who have not undergone therapy to have an adaptive coping mechanism (OR 12.467; 95\% CI 1.429108.736). Breast cancer patients who have finished therapy have a 14.958 times chance compared to breast cancer patients who have not yet undergone therapy to have an adaptive coping mechanism (OR 14.958; 95\% CI 2.213-101.105). The results of this analysis inform that therapy for breast cancer patients has a positive influence on adaptive coping mechanisms.

Therapy provides a calming effect for breast cancer patients. Breast cancer patients who have not been and are undergoing chemotherapy experience anxiety, depression, nausea, vomiting tend to ooze in their disorder. Breast cancer patients who have finished undergoing chemotherapy using coping mechanisms are more effective. The coping approach is mainly used by patients who see their disease as a challenge. Behavioral and cognitive aspects of coping decrease with the level of difficulty experienced by individuals ${ }^{9}$.

Breast cancer patients who received medium category social support had a 7.561 chance compared to breast cancer patients who received low category social support to have an adaptive coping mechanism (OR 7.561; 95\% CI 1.469-38.916). Breast cancer patients who received high category social support had 225.419 times the chance of breast cancer patients who received category low social support to have an adaptive coping mechanism (OR 225.419; 95\% CI 14.154-3589.974). The results of this analysis inform that social support has a positive influence on breast cancer patients to have adaptive coping mechanisms. The higher the social support provided, the more adaptive the coping mechanism is for breast cancer patients' adaptive coping mechanism breast cancer patients.

This finding reinforces the findings of previous studies that took the same theme. Other studies show social support for breast cancer patients not only directly increases emotional well-being, but also indirectly influences emotional well-being by influencing coping strategies ${ }^{10}$. Research in Norway also shows that social support is considered an undeniable resource when dealing with difficult life situations. Social support was positively related to instrumental-oriented coping and emotion-focused coping ${ }^{15}$.

\section{Conclusions}

Based on the results of the analysis found that 3 variables prove to be significant as determinants of coping mechanism among breast cancer patients in 
SidoarjoRegency, Indonesia. The three determinants are education level, therapy, and social support.

Acknowledgments: The author thanks to the scholarship provider, the Educational Fund Management Institute of the Republic of Indonesia through the Indonesian Flagship Scholarship in Indonesia (BUDI $\mathrm{DN})$.

Source of Funding: Educational Fund Management Institute of the Republic of Indonesia through the Indonesian Flagship Scholarship in Indonesia (BUDI $\mathrm{DN})$.

\section{Conflict of Interests: Nil}

Ethical Clearance: This study has been approved and passed the ethical test from the Faculty of Nursing, Airlangga University, Surabaya (No: 1255-KEPK). Respondents have provided written approval for their involvement in the study.

\section{References}

1. Charles Swanton SRDJ. Handbook of Metastatic Breast Cancer. 2nd ed. Informa,Healtcare; 2011.

2. Globocan. 2012. No Title Estimated Cancer Incidence, Mortality,Prevalence and Disabilityadjusted life years (DALYs) Worldwide in 2008. 2012;

3. Kemenkes RI, Informasi P data dan. Bulan Peduli Kanker Payudara_2016.pdf. Jakarta; 2016.

4. Lesley Fallowfield AC. Breast cancer. Ray Fitzpatrick and Stanton Newman, editor. London and New York: This edition published in the Taylor \& Francis e-Library, 2002.; 2002.

5. Luecken LJ, Compas BE. Stress, coping, and immune function in breast cancer. Ann Behav Med. 2002;24(4):336-44.

6. Shaheen G, Arshad M, Shamim T, Arshad S, Akram M, Yasmeen Z. Study Design Breast cancer patients referred to BINO were eligible to take part in the study. Base line demographic information was obtained on age, diagnosis; length of time since diagnosis and effects of treatment on physical and psychological health. 2011;(1):236-43.7. Nurachmah E. Dampak Kanker Payudara dan Pengobatannya Terhadap Aspek Bio-psiko-spiritual Klien yang Berpartisipasi Dalam Kelompok Pendukung Elly Nurachmah. 1996;(c).
8. Sutarna FN, Celine E, Tancherla A, Nathania R, Putri $\mathrm{H}$, Dharmaraja F, et al. The Association of Social Support and Coping Mechanisms in Breast Cancer Patients. Ann Oncol. 2019;30(October):vi147.

9. Cordella M, Poiani A. Behavioural Oncology. Behavioural Oncology. 2014.

10. Kim J, Han JY, Shaw B, McTavish F, Gustafson D. The roles of social support and coping strategies in predicting breast cancer patients' emotional wellbeing: testing mediation and moderation models. $\mathrm{J}$ Health Psychol. 2010 May;15(4):543-52.

11. Lazarus RS, Folkman S. Stress,appraisal and coping. New York: Springer Publishing Company New York; 1984.

12. Kozier EBS (2004). Fudamental of nursing: Concepts, process, and practice. Seventh Ed. New Jersey : Pearson Education. Inc.; 2004.

13. Stuart, G.W., and Laraia MT 2009., St. E, Book L: MY. Principles and practice of psyhiatric nursing 9 Th. 9 th ed. St. Louis : Mosby Year Book; 2009.

14. Sharma RK, Astrow AB, Texeira K, Sulmasy DP. The spiritual needs assessment for patients (SNAP): Development and validation of a comprehensive instrument to assess unmet spiritual needs. J Pain Symptom Manage. 2012;44(1):44-51.

15. Drageset S, Lindstrøm TC. Coping with a possible breast cancer diagnosis: Demographic factors and social support. J Adv Nurs. 2005;51(3):217-26.

16. Wulandari RD, Laksono AD. Education as predictor of the knowledge of pregnancy danger signs in Rural Indonesia. Int J Innov Creat Chang. 2020;13(1):1037-51.

17. Wulandari RD, Laksono AD. Determinants of knowledge of pregnancy danger signs in Indonesia. PLoS One. 2020;15(5):Article number e0232550.

18. Rohmah N, Yusuf A, Hargono R, Laksono AD, Masruroh, Ibrahim I, et al. Determinants of teenage pregnancy in Indonesia. Indian J Forensic Med Toxicol. 2020;14(3):2080-5.

19. Ipa $M$, Widawati $M$, Laksono AD, Kusrini I, Dhewantara PW. Variation of preventive practices and its association with malaria infection in eastern Indonesia: Findings from community-based survey. PLoS One. 2020;15(5):e0232909. 